\title{
Response of Superovulation by Using FSH (Follicle Stimulating Hormone) and Sex Determination of Embryos Using PCR in Pesisir Cows of West Sumatra
}

\author{
Tinda Afriani ${ }^{1 *}$, Ferry Lismanto Syaiful ${ }^{2}$, Dino Eka Putra ${ }^{1}$, Sumedi $^{3}$, Endang Purwati ${ }^{4}$ \\ ${ }^{1}$ Department of Genetic and Animal Breeding, Faculty of Animal Science, Universitas Andalas, Padang, 25163, Indonesia \\ 2 Department of Animal Reproduction, Faculty of Animal Science, Universitas Andalas, Padang, 25163, Indonesia \\ ${ }^{3}$ Division Farm and technology service Faculty of Animal Science, Universitas Andalas, Padang, 25163, Indonesia \\ ${ }^{4}$ Laboratory Biotechnology/ Technology of Animal Product, Faculty of Animal Science University of Andalas, Padang, \\ West Sumatera, Indonesia \\ Corresponding author email: tinda_a@yahoo.co.id
}

\begin{abstract}
This study was conducted to determine the response of superovulation by giving $16 \mathrm{ml}$ dosage of FSH hormone to female Pesisir cattle. The estrus schedule of 15 Pesisir cows was set by inserting CIDR (Controlled Internal Drug Release) into the vagina for 12 days. At day 10, all cattle were injected with FSH for three consequent days but with decreasing dosage. On the 3rd day, FSH injection was accompanied by $\mathrm{PGF}_{2 \alpha}$ injection and CIDR was removed. The detection of estrus was performed at day 13. Natural mating was proceeded after the estrus signs visible. Collection of donor embryos was done on the 6th and 8th day after mating. The variables measured were the response of superovulation, total number of corpus luteum, number of embryos and sex ratio. The results obtained were all Pesisir cows responded to superovulation. The average number of corpus luteum and embryos per cow were $5.93 \pm 3.17$ and 6.00 (61.64 \%), respectively, while the total of transferable embryoes were 90 , with an average of 6.00 or $61.64 \%$. The sexing of embryos obtained in this study from 146 embryoes awere $76.03 \%$ males (111 embryoes) and 23.97\% females (35 embryoes). Based on total of transferable embryoes, there were $51.37 \%$ male embryos and $11.28 \%$ of females embryos. The result of this study showed that the sex ratio of male embryos was higher than female embryos.
\end{abstract}

Key words: Pesisir Cattle, response of superovulation, FSH, corpus luteum, total of embryos, PCR and sex ratio of male and female

Abstrak. Penelitian ini dilakukan dengan metode eksperimen untuk mengetahui respon superovulasi pada dengan level dosis $16 \mathrm{ml}$ hormon FSH pada sapi Pesisir. Materi yang digunakan yaitu 15 ekor induk sapi Pesisir. Sapi Pesisir diatur jadwal berahinya dengan memasang CIDR (Controlled Internal Drug Release) pada vagina selama 12 hari selanjutnya pada hari ke-10 semua ternak diinjeksi dengan FSH. Injeksi FSH menggunakan dosis $16 \mathrm{ml}$ FSH dan pemberian FSH dilakukan dengan dosis menurun selama 3 hari. Hari ke-3 injeksi FSH diiringi dengan injeksi PGF $2 \alpha$ dan pencabutan CIDR. Deteksi berahi dilakukan pada hari ke-13. Kawin alam dilakukan setelah tampak tanda-tanda berahi dari ternak. Koleksi embrio donor dilakukan pada hari ke-6 sampai 8 setelah perkawinan. Variabel yang diamati adalah respon superovulasi, jumlah korpus luteum, jumlah embrio dan sex rasio embrio. Hasil yang diperoleh adalah respon superovulasi sapi Pesisir adalah $100 \%$. Rataan dari jumlah CL dan embrio sapi Pesisir adalah 5,93 $\pm 3,17$ dan jumlah embrio yang layak untuk ditransfer adalah 90 buah dengan nilai rataan 6,00 atau $61,64 \%$. Jenis kelamin embrio yang didapatkan dari 146 embrio pada penelitian ini, terdapat 76,03\% (111 embrio) dengan jenis kelamin jantan dan sebanyak 23,97\% (35 embrio) dengan jenis kelamin betina. Dari total embrio yang layak transfer terdapat $51,37 \%$ embrio berjenis kelamin jantan dan $11,28 \%$ embrio berjenis kelamin betina. Hasil penelitian ini menunjukkan bahwa rasio embrio berjenis kelamin jantan lebih tinggi dibandingkan dengan embrio berjenis kelamin betina.

Kata kunci: sapi Pesisir, respon superovulasi, FSH, corpus luteum, jumlah embrio, PCR dan sex rasio jantan dan betina

\section{Introduction}

Pesisir cattle is one of the indigenous Indonesian cattle which is mostly bred by farmers in West Sumatera, especially in the South Pesisir Regency. They are found spread over the coastal areas such as Padang Pariaman Regency, South Pesisir Regency, and Agam Regency (Anwar, 2004). Some desirable characteristics of this local cattle are its ability to adapt to low quality feeds and the traditional extensive production system, as well as the 
ability to resist tropical the diseases and parasites (Adrial, 2010).

Pesisir Cattle contributed significantly towards the supply of meat for people in the West Sumatera province, especially for qurban (sacrificial animal) on Eid al-Adha (Mosleem Feast Day). The need for beef in the population has increased by $2.0 \mathrm{~kg} / \mathrm{capita} / \mathrm{year}$ during the last 10 years (Victorbuana, 2010). For the last few years, the population of Pesisir Cattle has continuously declined and may lead to the extinction of this germplasm in West Sumatera. Artificial insemination (AI) and embryo transfer (ET) technology are the practical options to solve this problem. ET technology is used not only to accelerate the number of cattle population but also to provide the opportunity for embryo manipulation by gender adjustment of the embryo to increase the number of descendants for one type of sex in preservered aattle population. According to Afriani and Lismanto (2015), to optimize Al, estrus syncronization is needed by giving $16 \mathrm{ml}$ $\mathrm{FSH}+200 \mathrm{mg}$ GnRH injection. Furthermore, after the cow has successfully been induced for estrous, the Al process can be carried out. Then, on the sixth until eighth day after the $\mathrm{Al}$, the flushing/embryo harvesting can be conducted followed by sex determination using PCR technique. Chen et al. (2007) mention that the best sex determination technique is by PCR, because the method is simpler, accurate and inexpenssive. The advantage of sex determination of embryos is the increase on ecomonic efficiency in embryo transfer program. In this study, male sex identification was conducted when applying ET to generate male cattle in order to increase meat production.

\section{Materials and Method}

\section{Research Materials}

The sample of the study are: 15 healthy Pesisir Broodstock cows, 47 months of age and

2 parity. Consumable chemical materials includes some substances, such as CIDR (Control Internal Drug Release), FSH (Folltropin$\mathrm{V}$ brand produced by Bioniche Animal Health Canada Inc), PGF $2 \alpha$ (Capriglandin Inj brand produced by Caprifarmindo Labs, Bandung Indonesia).

The materials for flushing media, such as lactate ringer, lydocain, gentamycin and $5 \%$ calf serum, male cattle sperm, petridish, micropipette, pastuere pipette.

PCR material consists of bunsen burner, stereo microscope, PBS solution, calf serum, gentamicin, lactat ringer, lydocain, cotton, alcohol $70 \%$, Primer BRY, Kit RTG (pure Tag Ready-to-Go PCR Beads (Product Booklet), agarose $2 \%$ TBE solution $1 \mathrm{x}$ and ethidium bromide dye, loading dye (blue) double destilation water (ddH2O).

The utilized tools are straw, bunsen burner, Eppendroff microtube size $(1.5 \mathrm{ml} ; 0.5 \mathrm{ml}$ and $0.2 \mathrm{ml}$ ), vortex, microcentrifuge, PCR machine, observation camera of gels electrophoresis result, petridish, wipes, cotton, aluminium foil, stereo microscope, foley catheter, pasteure pipette, rubber tube, needle, embryo filter, stir bars, gun Al set, CIDR applicator.

\section{Research Prosedures}

The procedure of the study was as follow;

A. Superovulation

The 15 Pesisir cattle were given CIDR (containing progesterone); CIDR was dispositioned in front of the cervix for 11 days, then on day 10, FSH injection was given with the optimum dose given at noon for three days. The cows was given $16 \mathrm{ml}$ dose of FSH. On day 3, Gn RH was injected with the best dose at $200 \mathrm{mg} \mathrm{GnRH}$ based on a previous study. Once the estrus was detected Al was conducted on the cows.

\section{B. Flushing of Embryos}

On day 6th until day 8th after Al was conducted, flushing of embryos or harvesting was done with following procedures: the donor cattle was placed in a special restraining 
cage with the anterior part higher than the posterior part by 10 to $20 \mathrm{~cm}$. The reproductive organ was checked through rectal palpation, removal of excreta at the first place, followed by clinical examination of the cervix, uterus and ovaries and the number of corpus luteum on right and left ovary was counted. Moreover, epidural anesthesia with $2 \%$ Lydocain in $4-6$ $\mathrm{ml}$ was applied to ease the insertion of foley catheter and reduce defecation during the flushing process. Perineum, tail, vulva and the surrounding area are cleaned with water, lathered then rinsed with antiseptic solution and $70 \%$ alcohol. After the preparation was completed, the cervix was opened. The tools used were prepared to be aseptic and sterile before insertion to avoid the contamination in reproductiveorgans and to maintain the quality of the embryos. The insertion of the dilatators was done very carefully by using the right hand, while the left hand was used for the pre-rectal cervical fixation to guide the dilatators inclusion. The cervix inclution is proceed until the fourth cervical ring, until dilatators reach caudal part of the corpus uterus. Then, after the cervix has fully included, the foley catheter attached to Stilette Cassou Insemination Gun to make it stiff was prepared.

Foley catheter was lubricated by jelly and the inclusion is proceed aseptically. The Foley catheter inclusion through cervix also proceeds manually, the inclusion is done with the right hand, meanwhile, the left hand is proceeded pre-rectal cervical fixation to guide the insertion of Foley catheter into the cervix. The Foley catheter was inserted until it reached half of cornua uteri.

\section{Sex Determination of Embryo}

The sex determination of embryo was performed by utilizing PCR with the following procedure: superovulated embryo was placed inside the petridish, then the biopsy by using microblade was carried out. The blastomeres which had been excluded from the embryo were placed inside the petridish, washed three times with $10 \mu \mathrm{l}$ of PBS solution. 1 (one) or 2 (two) blastomers were placed into the RTG (Ready To Go) which had been added by $10 \mu \mathrm{l}$ double distilled water (ddH2O). Next, $5 \mu$ BOV $97 \mathrm{M}$ primers was added into RTG. Then, the PCR proceeded with electrophoresis by using 2 $\%$ agarose which had been added withethidium bromide. Further, DNA was added into the well using micropipette. The marker $1 \mathrm{~kb}$ is used, then buffer solution (TBE $1 x$ ) is added into the electrophoresis tools that is included agarose which contained DNA for 30 minutes. The result of electrophoresis was observed by utilizing UV rays (ultraviolet). Male embryo have two bands meanwhile female embryo have one band.

\section{Research Variable}

1. Response level of the superovulated donor cattle

The quantity of corpus luteum is dependent on the amount of corpus luteum in both ovary. The donor is considered as responding if it is contained $\mathrm{CL}$ greater than 1 (one) $(C L>1)$ and it is said as not responding if the $\mathrm{CL}$ is small or equal to 1 (one) $(\mathrm{CL} \leq 1)$.

2. Number of $\mathrm{CL}$ post superovulation

The number of $\mathrm{CL}$ in right and left ovary, the measurement is determined by rectal palpation.

3. The quality and quantity of the embryo The number of embryo which was collected from Pesisir cattle. The total number of embryos which was collected after embryo harvest and is observed under stereo microscope. The embryos, were characterized based on the grade; grade $A$, $B, C, D g$ (degenerative) and Uf (unfertile).

4. Sex determination
a. The effectivity of sex determination in embryo was by observing the amount of detected embryo using PCR.
b. Observing the steps of embryo development in which sex determination can be effective


c. Counting sex ratio of male and female in sex determination of Pesisir cattle.

\section{Results and Discussion}

The result of this showed that all (100\%) cows exhibited the estrus response due to the administration of FSH followed by PGF2 $\alpha$. It was based on the observation that the estrus indication appeared 24 hours after $\mathrm{PGF}_{2 \alpha}$ was injected to thePesisir cows. Ovulation appeared approximately 24.4 hours after the $\mathrm{GnRH}$ treatment was given to virgin cows $(81.5 \%)$ by injecting PGF ${ }_{2 \alpha}$ followed by GnRH 48 hours later (Kanitz et al., 2006). Heinonen et al.(1996) stated that estrus response in the cattle with intrauterine PGF $2 \alpha$ injection treatment was about $62.5 \%$ while the cattle with intramuscular $\mathrm{PGF}_{2 \alpha}$ injection treatment was about $60.6 \%$. Siregar et al. (2013) reported that PMSG insertion to goats also showed $100 \%$ of estrus response. $\mathrm{PGF}_{2 \alpha}$ injection will lead the estrus phase of the cattle into follicular phase, meanwhile for cattles that have no response towards the $\mathrm{PGF}_{2 \alpha}$ have the possibility of already passing the follicular phase or early luteal (Siregar et al., 2010).

In Tabel 1 it can be seen that $100 \%$ respond rate is obtained by using FSH $16 \mathrm{ml}$ dosages. This fact is related to Suradi's report (2004) that Simmental and Limousin cattles have $100 \%$ of superovulation respond. The respond of donor cattle that is obtained on FSH $16 \mathrm{ml}$ dosage is higher than the response from the previous research (Nanda, 2012) with the response rate of $66.67 \%$ on the same treatment, Maret (2001) got $85.70 \%$ response rate on $46 \mathrm{mg} \mathrm{FSH}$ dosage, while Muawanah (2000) got higher response rate value on the same dosage. Rahman et al. (2014) reported that $100 \%$ response rate is obtained from the injection of $200 \mathrm{mg} \mathrm{FSH}$ to Boer goat. Lehloenya et al. (2008) also reported that the injection of $200 \mathrm{mg} \mathrm{FSH}$ to Boer goat also gave $100 \%$ response rate on both breeding season or non breeding season.
The main obstacle in embryo production in beef cattle is the variability in the cows ovulation response towards superovulation with FSH injection (Rico et al., 2009). Cushman (1999) suggested that ovarium response to the superovulation treatment depends on the amount of small follicular population inside the ovarium. Basically, it is known that $25-30 \%$ of donor cattle have no or less reaction toward superovulation treatment (Supriatna and Pasaribu, 1992). The reasons of the low superovulation response are the increase in cattle lifespand (Muawanah, 2000), inappropriate nutrition of donor cattle and reproduction organ interference (Suradi, 2004). Baril et al. (1993) and Gonzalez-Bulnes et al. (2004) stated that the reason behind variable response to superovulation depend on extrinsic factor (the authenticity and purity of gonadotropin hormon (FSH and $\mathrm{LH}$ ) and superovulation treatment procedure (one or more dosage and hormon inclution) during the gonadotropin hormon inclution, season and ration influence) and intrinsic factor (cattle race, age and ovarium status at the treatment/mating moment). Ovary response towards superovulation can be different and it is strongly related to the variation of follicular development status during the treatment (Bo et al. 1995; Rajamahendran 2002; Sato et al. 2005).

The average of corpus luteum in Pesisir cattle after the injection of $16 \mathrm{ml}$ dosage of FSH was $2.97 \pm 1.69$, whicj was lower than that observed by Nilchuen et al. (2012) with the concentration of $200 \mathrm{mg}$ and $250 \mathrm{mg} \mathrm{FSH}$ administered in Kamphaeng Saen beef breed cows and heifers showing number of $\mathrm{CL}$ $8.67 \pm 0.98 ; \quad 7.33 \pm 0.98 ; \quad 10.33 \pm 0.98$ and $13.00 \pm 0.98$, trdpectively. Bülbül et al.(2013) got the $\mathrm{CL}$ average $8.4 \pm 1.6$ on twice a day injection of $400 \mathrm{mg} \mathrm{FSH}$ also $150 \mu \mathrm{g}$ D-cloprostenol together with the fifth FSH induction to Brown Swiss cattle race. Ali et al. (2012) reported that in local cattle of Bangladesh the injection 
of $320 \mathrm{mg} \mathrm{FSH}$ gave the best respond on the corpus luteum quantity $13.60 \pm 0.51$ meanwhile the lowest average is $8.60 \pm 0.60$ from the quantity of corpus luteum on $200 \mathrm{mg}$ FSH. Abdullah et al. (2011) got the $\mathrm{CL}$ number of average $2.7 \pm 0.7$ on $8.8 \mathrm{mg}$ FSH toward Boer goat. Rahman et al. (2014) reported that the injection of $200 \mathrm{mg} \mathrm{FSH}$ on the cross breeding goat (Boer $\mathrm{x}$ Katjang) got the $\mathrm{CL}$ average $6.40 \pm 1.55$.

In cattle, $\mathrm{CL}$ existence can be examined through rectal palpation. Generally, functional $\mathrm{CL}$ will be palpable on ovarium surface. FAO (2005) stated that a well trained practitioner who does the rectal palpation to examine the ovary for $\mathrm{CL}$ mat find two until three $\mathrm{CL}$. Sometimes, four to five embryoes are found. However, not every part of $\mathrm{CL}$ always clearly appear on the ovarium surface, as sometimes there are also unfunctional $\mathrm{CL}$ that cannot be be palpable.(Maidaswr, 2007). The differences of $\mathrm{CL}$ quantity which is produced by donor cattle indicated that every cattle have different responses towards gonadotropin treatment (Hafez, 1987). In addition, Rocha (2005) mentioned that the response differences are strongly related to ovary status at the beginning process of superovulation. Yusuf (1990) showed that in cattle that were given superovulation treatment an average of 7 or more $\mathrm{CL}$ were obtained which is categorized as high , $3-4 \mathrm{CL}$ as middle, and $0-2 \mathrm{CL}$ average as low. Whereas, Donaldson (1985) categorized $12 \mathrm{CL}$ per head into high category, $6-12 \mathrm{CL}$ as middle category and $0-5$ as low category. Based on the statement, the average of the $\mathrm{CL}$ quantity obtained from this research is categorized as middle. Saito (1997) enhanced that the level of ovary responses and embryo production has become two main parameters in analysing and interpretation of superovulation. The superovulation responde results in this study is shown in Table 1:

Table 1. Pesisir cattle superovulation respond after the injection of $16 \mathrm{ml} \mathrm{FSH}$

\begin{tabular}{ll}
\hline Superovulation Response & Amount \\
\hline The amount of treatment cattle $(\mathrm{n})$ & 15 \\
Estrus respond (\%) & 100 \\
Cattle that produce corpus luteum ( $\mathrm{n})$ & 15 \\
The amount of corpus luteum (n) & $54(1-6)$ \\
$\quad$ Right & $35(1-6)$ \\
Left & 89 \\
Total & $2.97 \pm 1.69$ \\
Average & 100 \\
The percentage of cattle producing corpus luteum (\%) & 15 \\
The number of cattle producing embryo (n) & 100 \\
The percentage of cattle producing embryo (\%) & 146 \\
Total embryo & $164 \%$ \\
Recovery rate(\%) & \\
The number of embryos according to grade & 44 \\
Grade A & 46 \\
Grade B & 37 \\
Grade C & 6 \\
Grade D & 13 \\
Degenerative fertilized & 6.0 \\
Average & 61.64 \\
The percentage of proper transfer (\%) &
\end{tabular}


The donor livestock is the animal where the embryo source is harvested (Seidel and Elsden, 1985). The value of the donor lifestock generally can be seen only from the ability to produce milk and meat. The donor livestocks should be healthy and good body condition because sick animals generaly have no response toward the ovulation treatment. Over weight or under weight body condition of donor animals can reduce the fertility (Herren, 2000). In addition, Wright (1987) stated that donor cattle must be free from the desease and abnormality movements, have good productivity record and measured estrous cycle.

The average number of embryos obtained from this study was 9.73 per cow with 90 (61.65\%) transfeable embryo from the total of 146 embryoes with an average of 6.0. Compared to the research results of cattle embryo obtained by Arum et al. (2013) and Siregar et al. (2012), the number of embryos harvested in this study was relatively high, in which the averages gain of embryo in sequences are 1.00 and 2.00, respectively, and the transferable embryoes are 1.00 and 1.10, respectively.

Compared to the number of $\mathrm{CL}$, there were more embryos collected in this study, with $164 \%$ recovery rate. This recovery rate was higher than those obtained by Maret (2001) (108.3\%) working on FH cattle, Maidaswar (2007) (105.81\%) in non lactating FH cattle, Simmental and Limousin, and (Prasetyo, 2012) (94 - 100\%) in FH Simmental, Limousin and Angus cattle. In Aceh cattle, Arum et al. (2013) obtained only $25 \%$ recovery rate. The reason for low recovery rate in this study was probably because of the small size of corpus luteum which render them undetectable during rectal palpation process (Maret, 2001). Moverover, it is said that non section embryo collection will cause $10 \%$ resulted embryo cannot be rinsed and it was still in the fallopian (Betteridge, 1980). Rensis and Scaramuzzi (2003) suggested that stress could also influence the quantity of embryos harvested from the cattle. Furthermore, Merton et al. (2003) suggested that the number of subordinate follicles in follicular wave pool will determine the embryo quantity of the donor.

Polymerase chain reaction (PCR) is the easiest and fastest technique for sexing in broad scale, the primer is from variative specific- $Y$ sequence which has been used to detect blood, meat and the blastomere of the samples (Zeleny et al., 2002; and Alves et al., 2003). This PCR technique is a DNA marker associated with the production of embryos according to the sex of the embryo genotype of the cattle (Peippo et al, 2007; Hirayama et al, 2008; Alonso et al, 2009). PCR is introduced as sexing molecular approach of embryo by using embryos cell after biopsy(Peura et al, 1991; Faber et al, 2003; Manna et al, 2003) which depends on the amplification of specific cromosom-Y with the sequence of DNA as the special indicator for male embryo and for an autosomal fragmen for both sexes male and female. Huhtinen et al. 91997) and Choi et al. (2009) reported that only embryos at the early stage (day 6.5, day 7, in the form of morula or early blastocysts) that has prognosis to stand on biopsy treatment.

The sex determination technique of embryo has economic benefit value because male cattle is more desired for beef than female cattle due to the better growth reason. Some researchers have published their research result that supports the suitability of the PCR method in sex determination for cattle based on the high accuracy and the speed in the presentation of the results of the sex ratio (Thibier and Nibart, 1995; Lopes et al., 2001; Ekici et al., 2006; Yu et al., 2007).

Normal sex ratio transformation has been connected to various condition like climate, food, stress, $\mathrm{pH}$ in the female genital tract, maturation and/or illumination process of sex cells and the age (Lawrence, 1941; McPhee, 1942 in Salisbury and Vandemark, 1985). 
$\mathrm{pH}$ condition inside the vagina control the sex determination where the acid condition influence the spermatozoa in some ways resulting in more the female calves while high $\mathrm{pH}$ will lead to male calves.

This study reveals that the percentage of male was $76.03 \%$ and female $23.97 \%$. The total number of transferable embryo contains $51.37 \%$ male embryoes and $11.28 \%$ female embryoes. Lopatarova et al. (2010) confirmed that female embryos were between $44-45.9 \%$ of the total embryos harvested. Shea (1999) and Lacaze et al. (2008) reported the same result for female sex determination ( $44-48 \%$ ) in every stage of embryo growth at day 6.5 and day 7.5. However, Hasler et al. (2002) reported the female embryo percentage (60.3\%) washigher than that found in this study.

In in vitro studies, it has been shown that the ratio of male in the embryos is higher than female (Kimura et al, 2008; Alonso et al, 2009). The number of male livestock arising from Artificial Insemination (Al) is generally higher than female livestock. This fact is in accordance with Payne's (1970) who stated that generally the livestock producedfrom artificial insemination is male because principally the sperm carrying male gene is stronger than the sperm carrying female gene. It can be seen that the difference between $X$ and $Y$ chromosome is the size of the DNA ( $\mathrm{Y}$ is smaller and $\mathrm{X}$ is bigger), surface change ( $X$ sperm moves to khatode) and motility ( $Y$ sperm is faster, $Y$ chromosome fluorescence). Male embryo (XY) will be appeared in two stripes with 141-bplong meanwhile for female embryo (XX) will be appeared in one stripe with 216-bp-long as shows in Figure 2.

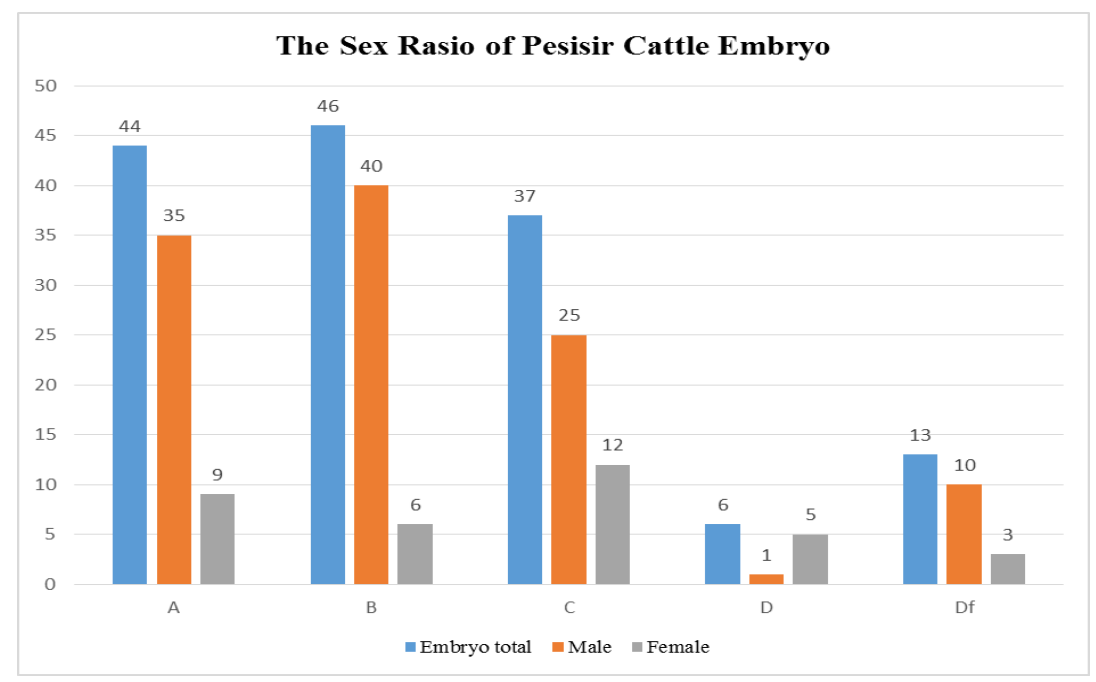

Figure 1. The diagram of the sex rasio of pesisir cattle embryo

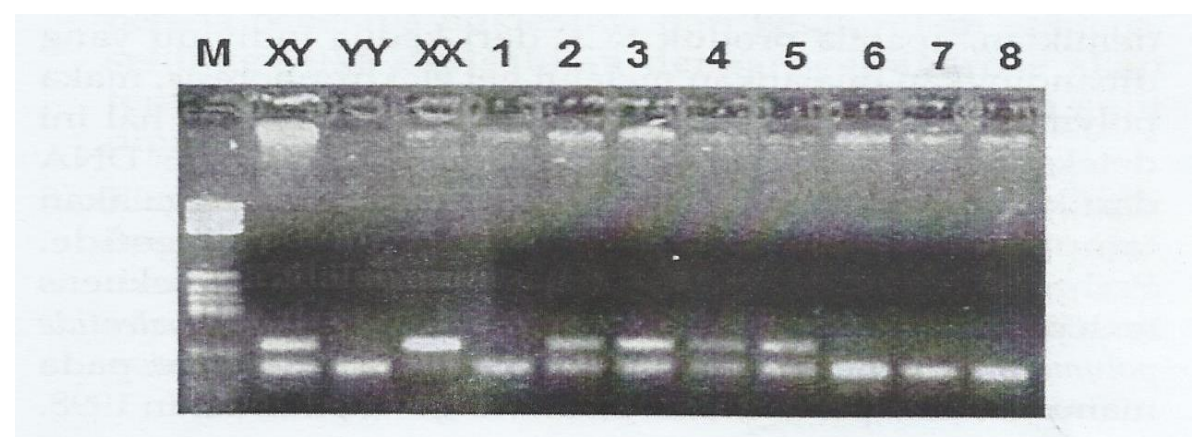

Figure 2. The appearance of a marking system of sex determination. $M$ is the standard size while $X X$, $Y Y$ and $X Y$ are the identification control $(X Y=$ male heterozygous, $Y Y=$ male homozygous and $X X=$ female). Source Jamsari (2007). 


\section{Conclusion}

From the result of this study, it can be concluded that Pesisir cattle injecte4d with 16 $\mathrm{ml} \mathrm{FSH}$ dosage injection resulted in the total 146 embryos that were collected and determined for sex $76.03 \%$ (111 embryos) were males and $23.97 \%$ (35 embryos) were females, and the total transferable embryos, $51.37 \%$ were males and $11.28 \%$ were females. The result of the research shows that the ratio of the male embryo was higher than female embryos.

\section{Acknowledgements}

This study was supported by a competitive grant research Universitas Andalas (020/SP2H/LT/DRPM/II/2016), This work was financially supported by Directorate of Research and Community Service, Ministry of Research, Technology and Higher Education of the Republic of Indonesia program. Thanks to Sumedi for technical assistance.

\section{References}

Abdullah, R.B., N.Y. Shariffah, M.R. Rahman' and W.E. Wan Khadijah. 2011. Effect of oFSH dosages in superovulation protocolon ovarian responses in goat. The $3^{\text {rd }}$ International Conference on Sustainable Animal Agriculture for Developing Countries (SAADC2011) July 26-29, 2011 Nakhon Ratchasima, THAILAND.

Adrial. 2010. Potensi sapi Pesisir dan upaya pengembangannya di Sumatera Barat. J. Litbang Pertanian. 29 (2) : 66-72.

Afriani, T dan F. Lismanto. 2015. Penerapan Bioteknologi Reproduksi Dengan Manipulasi Embrio Sapi Pesisir Sebagai Plasma Nutfah Sumatera Barat. Laporan Hibah Penelitian LPPM Unand, Padang.

Ali, M.S., M.A.M.Y. Khandoker, M.A. Afroz and A.K.F.H. Bhuiyan. 2012. Ovarian Response to Different Dose Levels of Follicle Stimulating Hormone (FSH) in Different Genotypes of Bangladeshi Cattle. Asian-Aust. J. Anim. Sci. Vol. 25, No. 1: 52 - 58.

Alonso, R.V., J.A.A. Hellu, S.H. V. Perri, J.A. Visintin, and J.F Garcia. 2009. Factors affecting commercial sexing program and multiple genetic analysis perspectives of in vitro produced bovine embryos. Reprod. Fert. Dev 21: 227.
Alves, B.C.A., V.F.M. Hossepian De Lima, C. M. Teixeira and C.A. Moreira-Filho. 2003. Use of primers derived from a new sequence of the bovine $Y$ chromosome for sexing Bos Taurus and Bos indicus embryos. Theriogenology, 56: 14151419.

Anwar, S. 2004. Kajian keragaman karakter eksternal dan DNA mikrosatelit sapi Pesisir Sumatera Barat. Disertasi. Pascasarjana IPB, Bogor.

Arum. W.P., T.N. Siregar dan J. Melia. 2013.Efek pemberian ekstrak hipofisa sapi terhadap respons superovulasi sapi Aceh. J. Med. Vet. Vol. 7 No. 2: 71-74.

Baril, G., P. Brebion and P. Chesne. 1993. Manuel de formation pour la transplantation embryonnaire chez la brebis et la chevre, Vol. 115. (Food and Agriculture Organisation of the United Nations; Rome, Italy.) [In French].

Bo, G.A, G.P. Adams, R.A. Pierson, R.J. Mapletoft. 1995. Exogenous control of follicular wave emergence in cattle. Theriogenology, 4: 31-40.

Bülbül, B., M. Kirbaş, Ş. Dursun and M. Köse. 2013. Superovulation in cows synchronized with two different progesterone+oestradiol protocols. Archiv Tierzucht 56 (15) 160-168.

Chen, A., X. Zi-rong and Y. Song-dong. 2007. Sexing goat embryos by PCR amplification of X- and Ychromosome specific sequence of the Amelogenin gene. Asian-Aust. J. Anim. Sci. Vol. 20, No. 11: 1689-1693.

Choi, Y.H., D.L. Hartman and K. Hinrichs. 2009.Viability of equine blastocysts subjected to biopsy for preimplantation genetic diagnosis. Reprod, Fert and Dev. 21: 166-167.

Cushman, R.A., J.R. Wood, R.G. Slattery, D.T. Clopton, J. Smith, K.A. Beavers, W.E. Pohlmeier, J.W. Bergman, K.V. Moline, A.S. Cupp. 2010. Reproductive aging influences ovarian function in beef cows. Nebraska Beef Cattle Reports, 558.

Donaldson, L.E. 1985. Estimation of superovulation responses in donor cows. Vet. Record. 117: 3334.

Ekici, H., N. Turan, B.H. Sontas, C.R. Helps, A. Senunver, H. Ylmaz. 2006. Sex determination of bovine embryos using polymerase chain reaction (PCR). Revue de Medicine Veterinaire, 157: 441444.

Faber, D.C., J.A Molina, C.L. Ohlrichs, D.F. Vander Zwaag, L.B. Ferré. 2003. Cemmercialitation of animal biotechnology. Theriogenology, 59: 125138.

FAO. 2005. Training Manual For Embryo Transfer In Cattle. Animal Reproduction Laboratory, Colorado State University, Fort Collins, CO 80523, USA.

Gonzalez-Bulnes, A., D. T.Barid, B. K. Campbell, M. J.Cocero, R.M.Garcia-Garcia, E.K.Inskeep, 
A.Lopez-Sebastian, A.S.McNeilly,J. SantiagoMoreno, C.J.H.Souza, and A.Veiga-Lopes. 2004. Multiple factors affecting the efficiency of multiple ovulation and embryo transfer in sheep and goats. Reprod. Fert and Dev. 16: 421-435.

Hafez, E.S.E. 1987. Reproduction and Breeding Techniques for Laboratory Animals. Lea and Febriger, Philadelphia.

Heinonen K, Shieferans T, Heinonen M. 1996. Oestrus synchronization in Ethiopian highland zebu cattle by means of intravaginal cloprostenol administration. Trop Anim HIth Prod, 28:121 125.

Herren, R. 2000. The Science of Animal Agriculture. 2nd Ed. Delmar Thomson Learning, Albany.

Hirayama, H., A. Fujikawa, S. Kageyama, S. Moriyasu, K. Sawai, S. Onoe, and A. Minamihashi. 2008. Multiple genotyping in bovine pre-implantation embryo with whole genome amplification. Anim. Sci.79: 554-560.

Huhtinen M, Peippo J, Bredbacka P. 1997. Successful transfer of biopsied equine embryos. Theriogenology, 48: 361-367

Kanitz. W., S. Bhojwani, F. Becker and F. Schneider. 2006. Follicular Dynamic and Characteristics of Ovulations in Heifers after Ovsynch Treatment in The Last Third of the Estrous Cycle.

Lehloenya, K.C., J.P.C. Greyling, S. Grobler. 2008. Effect of season on the superovulatory response in Boer goat does. Small Ruminant Research, 78: 74-79.

Lopes, R.F.F., F. Forell, A.T.D. Oliveira, J.L. Rodrigues. 2001.Splitting and biopsy for bovine embryo sexing under field conditions. Theriogenology," 56: 1383-1392.

Maidaswar. 2007. Efisiensi Superovulasi pada Sapi Melalui Sinkronisasi Gelombang Folikel dan Ovulasi. Tesis. Pascasarjana Institut Pertanian Bogor, Bogor.

Manna, L., G. Neglia, M. Marino, B. Gasparrini, R. Di Palo, and L. Zicarelli. 2003. Sex determination of buffalo embryos (Bubalus bubalis) by polymerase chain reaction. Zygote. 11: 17-22

Maret, D. 2001. Pengaruh dosis follicle stimulating hormone (FSH) dan body condition score (BCS) terhadap superovulasi sapi perah Fries Holstein (FH). Skripsi. Fakultas Peternakan, Institut Pertanian Bogor, Bogor.

Merton, J.S., A.P.W. de Roos, E. Mullaart, L. de Ruigh, L. Kaal, P.L.A.M. Vos and S.J. Dieleman. 2003. Factors affecting oocyte quality and quantity in commercial application of embryo technologies in the cattle breeding industry. Theriogenology, 59:651-674.

Muawanah. 2000. Superovulasi pada sapi perah Fries Holland (FH) dengan pemberian dosis $\mathrm{FSH}$ yang Berbeda. Skripsi. Fakultas Peternakan. Institut Pertanian Bogor, Bogor.

Nanda, M. 2012. Respon superovulasi sapi Pesisir dan sapi Simental. Tesis. Program Pascasarjana Universitas Andalas, Padang.

Nilchuen, P., S. Rattanatabtimtong and S. Chomcai. 2011.Superovulation with different doses of follicle stimulating hormone in Kamphaeng Saen beef cattle. Songklanakarin J. Sci. Technol. 33 (6), 679-683.

Peippo, J., S. Viitala, J. Virta, M. Raty, N. Tammiranta, T. Lamminen, J. Aro, H. Myllymaki, and J. Vilkki. 2007. Birth of correctly genotyped calves after multiplex marker detection from bovine embryo microblade biopsy. Molecular. Reprod. Dev. 74: 1373-1378.

Peura, T., J. M. Hyttinen, M. Turunen and J. Janne. 1991. A reliable sex determination assay for bovine preimplantation embryos using the polymerase chain reaction. Theriogenology. 35(3): 547- 555.

Prasetyo, D. 2012. Tingkat superovulasi pada beberapa bangsa sapi dengan sumber follicle stimulating hormone (FSH) yang berbeda. Skripsi. Fakultas Peternakan. Institut Pertanian Bogor.

Rahman, M. R., M. M. Rahman, W.E. Wan Khadijah and R.B. Abdullah. 2014. Comparison of superovulatory effect of equine chorionic gonadotrophin and follicle stimulating hormone on embryo production in crossbred (Boer $\times$ Katjang) goats. Pakistan J. Zool., Vol. 46(3): pp. 819-826.

Rajamahendran, R. 2002. Advanced Technology in Molecular Biology and Biotechnology of Farm Animals. Faculty of Agriculture The University of British Columbia, Vancouver, Canada.

Rensis, F.D. and R.J. Scaramuzzi. 2003.: Heat stress and seasonal effects on reproduction in the dairy cow - a review. Theriogenology 60, 1139-1151.

Rico, C., S. Fabre, C. Medigue, N. Di Clemente, F. Clement, M. Bontoux, J.L. Touze, M. Dupont, E. Briant, B. Remy, J.F. Beckers, D. Monniaux. 2009. Anti-mullerian hormone is an endocrine marker of ovarian gonadotropin-responsive follicles and can help to predict superovulatory responses in the cow. Biol. Reprod. 80, 50-59.

Rocha, E.H.R. 2005. Analysis of record of embryo production in Red Brahman cows. Thesis. Texas A\&M University.

Saito, S. 1997. Manual on Embryo Transfer of Cattle. National Livestock Embryo Centre (BET Cipelang)DGLS and Japan International Cooperation Agency (JICA).

Sato T., K. Nakada, Y. Uchiyama, Y. Kimura, N. Fujiwara, Y. Sato, M. Umeda and T. Furukawa .2005. The effect of pretreatment with different doses $\mathrm{GnRH}$ to synchronize follicular wave on 
Tinda Afriani, et al. /Animal Production. 20(1):7-16, 2018

Accredited by Kemenristek Dikti No 32a/E/KPT/2017. ISSN 1411-2027

superstimulation of follicular growth in dairy cattle. J of Reprod and Dev, 51(5): 573-578.

Seidel, G.E. and Elsden, R.P. 1985. Procedurs for

Recovery, Bisection, Freezing and Transfer Bovine Embryos. Colorado (AS): Colorado State Univ.

Siregar, T.N., I.K. Siregar, T. Armansyah, Syafruddin, A. Sayuti dan Hamdani. 2013 Tampilan reproduksi kambing lokal hasil induksi superovulasi dengan ekstrak pituitary. Jur Vet. 14(1):75-79.

Siregar, T.N., T. Armansyah, A. Sayuti, Syafruddin. 2010. Tampilan reproduksi kambing betina lokal yang induksi berahinya dilakukan dengan sistem sinkronisasi singkat. Jur. Vet. Vol. 11 (1): 30-35.

Siregar, T.N., T. Armansyah, A. Sayuti, Syafruddin. 2010. Tampilan reproduksi kambing betina lokal yang induksi berahinya dilakukan dengan sistem sinkronisasi singkat. Jur. Vet. Vol. 11 (1): 30-35

Suradi, 2004. Kualitas embrio hasil inseminasi buatan (IB) sapi Limousin dan Simental dengan sapi Bali. Skripsi. Fakultas Peternakan. Institut Pertanian Bogor, Bogor.
Thibier, M. and M. Nibart. 1995. The sexing of bovine embryos in the field. Theriogenology, 43, 71-80.

Victorbuana. 2010. Peluang Usaha Ternak Sapi Potong. PeluangUsaha.web.id

Wright, R. 1987. Present Status of and Prospects for Embryo Transfer in the United States. In: Technical Meeting on Embryo Transfer and Animal Production. National Academy Press, Washington DC.

Yusuf, T.L. 1990. Pengaruh Prostaglandin $F_{2 \alpha}$ dan Gonadotropin terhadap aktivitas estrus dan superovulasi dalam rangkaian kegiatan transfer embrio pada sapi Fries Holand, Bali dan peranakan Ongole. Disertasi. IPB Bogor.

Yu, W., S. Li, J. Fang, X. Sun, L. Cui, J. Fu, Y. Bai, Y. Fang and B. Shangguan. 2007: Field studies on the effectiveness of the YCD embryo sexing technique in bovine. Reprod. Fert. and Dev, 19: 299-300.

Zeleny, R., A. Bernreuther, H. Schimmel and J. Pauwels. 2002. Evaluation of PCR-based beef sexing methods. J. Agric. Food. Chem. 50: 41694175. 